\title{
Women Entrepreneurs In India: Challenges And Opportunities
}

\author{
Dr. Anjula Rajvanshi \\ Associate Professor, Department of Sociology, RG PG College, Meerut
}

\begin{abstract}
In this era of globalisation, Indian women are playing a magnificent role in the progress of their country and trying to increase and raise the real per capita income. In rural areas, women are helping in agricultural work with the male family members. They are not earning money in that time but they are saving money.
\end{abstract}

\begin{abstract}
Women's entrepreneurship has been recognized during the last decade as a new jobs and success for themselves and others also. By providing this, they are giving different ideas, jobs and solutions to management, organization and business problems as well as women exploitation. Although the number of women entrepreneurs are very less but they are doing their best. Because of the male dominated society, women entrepreneurs are largely neglected in normal life of society and basically a woman and her family members have a concept for job to her as a teacher, tutor or government officer/ worker. They are unable to accept them as R\&D incharge, IAS/PCS/CID, business lady, factory maker, engineer, etc. But today if we see the backside of mirror, then we will find successful women entrepreneurs. We can collect the full profile of women entrepreneurs, their demographic information barriers to start-up, growth and problems to perform their duties in family as well as in society. The biggest and better example of self-employment is Lizzat Papad. Women are doing very well in the field of business but its small scale business. Thus, we can quote these small business ladies as entrepreneurs.Most specifically for women's entrepreneurship, we should try to change the interests and attitude of women and society. We feel that many women entrepreneurs are busy in retailing and simple manufacturing with very little growth potential or they are just focusing on education and health care. If women entrepreneurs will come in the picture of business, Indian society will increase its social capital with social, political, legal, cultural and business values. In my research paper, I emphasized on the challenges and opportunities for Indian women entrepreneurs of Meerut city of Uttar Pradesh, India.
\end{abstract}

Individual, social and economic development can easily made through proper human resource management. Our Prime Minister Mr Narendra Modi is focusing on self employment through start up programme, skill development programme, Pradanmantri Kaushal Kendra training centres, social welfare department and banks. He emphasized on utilize the Indian man power properly to control mass poverty and widespread unemployment. Development of entrepreneurship has to be in top priority of Indian leaders and elites.

Dr. Sudha Pandey (D.Litt. Member Public Service Commisssion, Uttaranchal) wrote in Foreword of Zainab Rahman's book i.e. Women and Society (2005), "Women have had to struggle continuously to establish their identity as independent individuals in society. It is essential that besides enhancing their physical, mental and other capabilities, on an equal footing as men, they should be able to make their own decisions, have equal access to opportunities in different fields and be looked upon as 'persons' not 'objects'." Zainab Rahman (2005:15) confirmed it in his book that 'India is a typical example where equal status and rights have been granted since independence and a small number of educated women have achieved equality in various fields but by and large, women are still discriminated against in myriad ways, exploited and subjugated.'

Now a day's every profession is giving opportunity to both genders. Now fight is to show their capability, good communication skill, ideal management, progressive attitude, innovative nature, open views, commands the mass etc. Women are a good manger since their starting. But they are ignored. Now women are playing their vital and impressive role to confirm this. Women empowerment is the first step to organize every field of society either family or any corporate sector. In this context Anita Stephen (2006: 5-6) said that 'Empowerment of women in the context of knowledge societies is understood as building the ability and skills of women to gain insight of actions and issues in the external environment which influence them, and to build their capacity to get involved and voice their concerns in these external processes, and make informed decisions. It entails building up of capacities of women to overcome social and institutional barriers, and strengthening their participation in the economic and political processes for an overall improvement in their quality of lives' 
Indian society is basically based on cultural harmony and perfect division of labour. It's dominated by man due to the outdoor work and overall security. We think that women will be safe in four walls of a house. But it is not possible or right from the starting of society till the end. A country could progress only when both genders (male and female) work together, eat together, sit together, perform their duties together and be progressive together. Prof. M.B Shukla (2007:3) explained in his research paper that society and government can play its important role to develop entrepreneurship. Development of entrepreneurial class is a direct function of ethical value system of the society concerned. Max Weber opined that the spirit of rapid industrialization depends upon a nationalised technology, acquisition of money and its rationale use for productivity and multiplication of money.These elements are generally governed by specific value orientation of individuals like the tendency of acquisition and rational attitude towards action which are generated by ethical value. Max Weber further view that there is positive relationship between protestant ethic and the spirit of capitalism in the Indian context, Hindu Vaisya, Jain and juda are quite effective in developing and entrepreneurial class. Actually, entrepreneurship develops rapidly in those societies .where ethical values provide independent capacity of decision - making. According to Tiwari and Tiwari (2007: preface), 'women are the nuclei of the nation .they are the real builder and moulder of a nations destiny. The position and the status of women in any society in an index of its civilisation and progress. Indian women are considered as source of power or SHAKTI since mythological times. Women who constitute 46.5 per cent of total population and 28.9 percent of work force are out of total female population only 9 percent of entrepreneurs. The rural women, at the same time constitute nearly 77 percent of the total female population and play a significant role in agriculture, allied sectors and artisanal activities. The population of women entrepreneurship necessitates to remove social, economical and educational constrain. Through more than half-a-century has passed after independence, development of women entrepreneurship has not been rapidly achieved as the other measures of development.'

\section{WOMEN ENTREPRENEURSHIP AND INDIA}

After independence, several legislative acts were passed like the special act of 1954, the Hindu marriage act of 1955 and the Hindu succession act of 1956, the hindu adoption and maintenance act of 1956 , and the dowry prohibition act, 1961, the maternity benefits act ,1961 the equal remuneration act, 1976 and the criminal law amendment act, 1983 . These acts have been introduced to remove constrains hindering the progress of women.

Bajpai \& Mishra (2007) present their project in the form of a book i.e. Women Empowerment and Reproductive Behaviour. They we gave their strong recommendations for women empowerment in india.Two recommendations are relevant to this study -

- Concept of women empowerment in Indian context has to be different from that of western countries. Women empowerment must be conceptualized to abolish both. 'Parivar Liptata' and 'Parivar Muktata' and ensure 'Parivar Nishthata' in both males and females.

- Women empowerment is a social responsibility. The movement launched for this should not hesitate to take cooperation also of males to reap out the gains of decline in gender sensitization in males, spontaneously occurring in due course of time.

Sethi and Singhal (2015:6-7) wrote in his paper about Social Entrepreneurship. They explained, "Social entrepreneurship is generally referred to as a multi-disciplinary access as this pertains to a variety of areas in human and professional life of an individual. This concept is undertaken for those individuals or business organizations that went to find explanations for social obstacles with the help of business craft and know how .Social entrepreneurs are more interested in taking into consideration what they have done for the society rather than the profit that they have earned these ventures. These social organizations customarily undertake to facilitate wide ranging civil, developmental and ecological objectives usually linked with the noon profit establishments." In this research paper they quoted the views of Christian Seelos and Johanna Mair. Christian Seelous and Johanna Mair in their article titled "Social Entrepreneurship: Creating New Business Models to Serve the Poor" state that the term "Social Entrepreneurship"(SE) is used to refer to the rapidly growing number of organizations that have created models for efficiently catering to basic human needs that existing markets and institutions have failed to satisfy. Social Entrepreneurship combines the resourcefulness of traditional entrepreneurship with a mission to change society.

In this era of globalisation, Indian women are playing a magnificent role in the progress of their country and trying to increase and raise the real per capita income. In rural areas, women are helping in agricultural work with the male family members. They are not earning money in that time but they are saving money. In urban areas, especially in developing countries, Indian women are actively participating in two sectors organized and unorganized. K.D. Gaur and J.L. Singh (2002:173-174) said - 'The concept of unorganized sector is not a new concept but what is new is the connotation given to this term in recent years. The term unorganized, 
unregulated, traditional household and informal are used interchangeably in contrast with organized regulated, modern, corporate and formal sectors.'

Women entrepreneurs are mostly concentrate on printing press, agriculture, horticulture, sericulture, dairying and animal husbandry, fisheries, handicrafts ,beedi making, agarbatti making , tailoring, garment industry ,saree and dress design up \& fall -button serving, purse making and designing, doll making, pottery, blacksmith industry, jewellery, beauty parlours, textile printing, electronics, chemicals food processing's, nurseries, baby care centres, stationary products, badi-papad making, chat \& food items, refilling of items, craft project, assignment making, computer centres, training centres, bulb box making, Tiffin supply, etc.

As we are here to discuss the topic Indian Women Entrepreneurs: Challenges and Opportunities, I want to write the objectives of this study. I will discuss:

1. The old and new field of entrepreneurship for ladies.

2. Problems in women entrepreneurship.

3. Challenges for women entrepreneurs.

4. Opportunities for women entrepreneurs.

5. Suggestion to the government and policy makers.

6. Suggestions for new generation as upcoming women entrepreneurs.

\section{WHAT IS WOMEN ENTREPRENEURSHIP?}

Women entrepreneurship is the entrance of women in the corporate world with their new business techniques. Women may be considered to be an entrepreneur if she has started a business alone or with other women or is someone, who is principal in a family business or partnership or is someone who is shareholder and manager in publicity held company. But most of the time, I found that women is working on their family business without any decision making power and recognition. Dr. A K Srivastava \& Satish Ailawadi (2007: 19) certified this in their paper that 'Various researchers have shown that women contribute to a very large extent to their family businesses that go unnoticed and unappreciated. It is observe that the family members tend to ignore the efforts of their women in enterprise. Many of such enterprises where women hold the controlling shares are in fact run in their names by men and who control operations and decision - making.'

When we hear about Indian women entrepreneurs we feel strange but do we actually know their contribution, in our country's progress? There is no need to look at distance for realizing women talents. You look around your surroundings. Many coaching institutes, beauty parlours, pickle / candle / bulb / Namkeen / Papad/ tailoring shop / computer institutes / music classes / shops of ladies items/ general store/ medical store/ canteen / STD PCO shop/ agarbatti making factories.

Women's entrepreneurship has been recognized during the last decade as an unforgettable source of financial growth. Women entrepreneurs are trying to open the door of new jobs and success for themselves and others also. By providing this, they are giving different ideals, jobs and solutions to management, organization and business problems as well as women exploitation. Although the number of women entrepreneurs are very less but they are doing their best. Because of the male dominated society, women entrepreneurs are largely neglected in normal life of society and in the research work of social sciences, etc. basically a woman and her family members have a concept for job to her as a teacher, tutor or government officer. They are unable to accept them as R\&D incharge, IAS/PCS/ CID, business lady, factory maker, engineer, etc. But today if we see the backside of mirror, then we will find successful women entrepreneurs.

According to Professor Cary Cooper (Head of Organization Psychology at Manchester University) quoted in Veronica Groocock's book i.e. Women Means Business, there is a paradox in the psychological battle between the sexes: "Intellectually, men want their wives to be better educated. Psychologically, they are unable to cope with it- it's still the mother-at-home model they think about." Although, women have in general a lower social position than man, which affects the kind of networks they access or are part of. There are evidences to prove that women are less involved in networks than men are and their type of network is different. For business, it is important to have weak-tie networks as strong ties. 3 The strong and personal networks that women traditionally engage in are well suited for purposes linked to the family related tasks that may prove to be a hindrance in the market place. 4 Thus women differ to men in the kind of networks they use and in the social capital available to them through the network. Women have therefore less access to critical resources, support and information needed to successfully start and manage a new firm compared to men.

Dr. Shashi Saini (Dec.2016: 39) discussed the multi- role responsibility and attempts to negotiate them in her research paper. She said that Professional women take on multiple roles in daily life. Some roles are by choice and other roles are chosen for women. Along with the work responsibilities women roles often include daily household chores, family and social obligations, caretaking for children/ elderly parents as well as other roles. As the experiences of these women professionals' shows that their different roles emerged as a source of conflict because they struggle hard with the daily pull raising a family or caring for elderly parents and other 
social obligations along with their career demands and commitments. They felt that their domestic responsibilities which traditionally viewed as women domain inhibited the pace of their career progression compared to their male colleagues.

According to C. G. Brush (1992: 6), In general, women have lower personal financial assets than men. This means that for a given opportunity and equally capable individual, women must secure additional resources compared to men in order not to waste the opportunity, only because they control less capital. A question that has been developed into its sub-field in the women's entrepreneurship literature is if women have a harder time getting finance than men for the same business opportunity. Several results stand out from different literature reviews.

We can collect data about the full profile of women entrepreneurs, means, demographic information barriers to start-up, growth and problems to perform their duties in family and society, we can be in touch with Internet or contact with self-employed ladies. The biggest and better example of self-employment is Lizzat Papad. Women are doing very well in the field of business but its small scale business. Thus, we can quote these small business ladies as entrepreneurs. Those ladies who are helping their husband's business are entrepreneurs or not?

By searching internet, I came across many success stories of women entrepreneurs. Vrindha Rajgarhia's story is one out of them, who runs a confectionary shop in which Marwari women do. They just take over the family business. I think doing my own has given me a lot of satisfaction than just joining the existing family business." This is not her first business. She tried one earlier which was a hosiery manufacturing setup. This probably indicates that her family wasn't averse to her starting another venture, just because the first one failed. The idea for the confectionary store didn't just grow up. She would have been thought about it for a while but the tax structures prevented her from being a viable enterprise. As soon as the taxes or the duties on the goods were reduced, she was able to commence operations. The enterprise is still not in a "traditional" business domain. In the sense it reflects one of the issues highlighted in the ILO report of women entrepreneurs - "Women have a proportionality greater pressure in the informal economy and in microenterprises; and they are less represented in formal, registered SME's."

While this story is a successful one, the fact of the matter is that in a strongly patriarchal society like India masculine hegemonies make it extremely difficult for women to start and succeed in their own ventures. Here are some of the issues I have either been read about or seen women face having lack of family support, lack of capital, lack and confidence and faith, lack of right, public and private institutions. These are the factors due to which Indian women are unable to make their contribution in the progress of themselves and society as well as their country also.

Today women are trying to join computer business, confectionary business, general items business, vegetables or fruits business, stationary shops, printing press, newspaper business, publication business, writing books business, mobile shop holders, coaching institutions, tea stalls, medical stores, hospital business, automobile business, etc. It's a great change in women's thinking and culture. They are trying their level best. They are not afraid of taking risks. Are they not women entrepreneurs? They are also making their business by their own efforts. They are taking loans from private or government sectors. They are facing the opposition by their family members. But they feel secure, creative, self confident, happy, busy and self made, economically bold personality. All these are their personal efforts and works.

III.

REVIEW OF LITERATURE

In the era of globalisation, market is also busy with globe business pattern. Its quite easy to work on a computer or mobile to sell their products and purchase the material in maximum low prices. Anita Stephen (2006:98-99) is focusing on the global marketing system of developing countries. She said that, The position of women, even in the developing world, has been far from uniform or unilinear in this emerging global scenario. In some developing countries, such as India or the Philippines, women have become major recipients of this globally distributed work. In addition, digitisation of information and the internet have made it possible to sell goods and services beyond the boundaries of national states. The market for e-business and e-commerce is, at least potentially, global. Hence the internet, if and when available, makes it technologically possible to have access to global knowledge that includes prices, markets and tools. It has strengthened their ability to more effectively complete even in the domestic market. When they have been included in the digital economy, women have benefited by having access to: global markets; - global distributed works; - global knowledge. Nevertheless, in spite of the new opportunities that ICT has offered to women, one can only be cautiously optimistic. The success of women has so far been limited to a handful of countries. The beneficiaries are generally from urban areas, whereas the majority of women, even in the high profile Asian countries, live in rural areas where connectivity is rare or non existent .Women are generally engaged in meeting local and family needs and are overwhelmingly not linked to a global digital economy that is essentially geared to trade and anchored in market transactions. Exclusion implies missed opportunities and a widening of the gap in material well-being between the excluded and the included. Since women from the majority of the poor in most 
developing countries, exclusion affects more women than men. There is thus a strong case to be made in applying a gender focus to policy analysis in relation to globalisation. According to the report of organization for economic cooperation and development (Istanbul, Turkey, 3-5 June 2004, page no.6) "Women's entrepreneurship is both about women's society and the role of entrepreneurship in the same society. Women are faced with specific obstacles (such as family responsibilities that have to overcome in order to give them access to the same opportunities as men. Also, in some countries, women may experience obstacles with respect to holding property and entering contacts. Increased participation of women in the labour force is a prerequisite for improving the position of women in society and self employed women."6

The report finds that women entrepreneurs play an important role in the entrepreneual economy, both in their ability to create jobs for themselves and to create jobs for others also. In Europe (both in European Union Countries and other European countries), estimations indicate that there exists more than 10 million self employed women. In the United States, 6.4 million self employed women provide employment for 9.2 million people and create significant sales. Using the united states ratio between the number of employees and self employment, it may be estimated that employed women surveyed in European countries could employ around 15 million persons. There is a conservative estimation.

A prerequisite for starting a firm is to have capital in terms of financial assets and in terms of relevant knowledge assets. Women's position in society has led to a lack of assets in both these aspects. The constraints of family obligations make it harder for women to take on work on a full time basis and to engage in a career. This has in turn decreased the range of possible sectors. Being a part time worker with low pay is not a good basis for creating personal wealth. Moreover networks are important because our actions are shaped by our context, congesting of the system of individuals with whom we interact. "Social network theory has its objective to explain how status is attained in society or how social capital can be utilised to achieve goals."7

If we want women entrepreneurs in Indian society, the need of women entrepreneurs should be completed by the Government and family members. If no gender difference found in workplace and try to arrange the proper facility for their children, they can work hard and in better way. Government should try to hear the views, voices and ideas of women, try to motivate women to join business, try to give them promotion and best working conditions by the evaluation and the analization of their work. If women entrepreneurs will be in society, then many of women workers will feel familiar atmosphere in the working place. No doubt, women are better source to make a society economically bold and solid.

By this table, we can show the economic impact of women entrepreneurs in different countries such as Canada, Germany, Sweden, South Korea, United Kingdom and United States -

Table 1 - Economic impact of women entrepreneurs

\begin{tabular}{|c|c|c|c|}
\hline Country & Economic Impact & Year & Source \\
\hline \multirow[t]{3}{*}{ Canada } & $\begin{array}{l}\text { There are more than } 8,21,000 \\
\text { women entrepreneurs and they } \\
\text { contribute to an excess of CAD } 18 \\
109 \text { billion to the economy } \\
\text { annually. }\end{array}$ & 2003 & $\begin{array}{l}\text { The Prime } \\
\text { Minister's task } \\
\text { force on women } \\
\text { entrepreneurs } \\
\text { report and } \\
\text { recommendation }\end{array}$ \\
\hline & $\begin{array}{l}\text { Between } 1981 \text { and } 2001 \text {, the } \\
\text { number of women entrepreneurs } \\
208 \% \text {, compared with a } 38 \% \\
\text { increase for men. }\end{array}$ & & \\
\hline & $\begin{array}{l}\text { Average annual sales for women- } \\
\text { owned firms are significantly } \\
\text { lower. In 2000, women-owned } \\
\text { SMEs averaged CAD } 311289 \text { in } \\
\text { sales, compared with } 654294 \text { in } \\
\text { sales for firms owned by men. }\end{array}$ & & \\
\hline \multirow[t]{2}{*}{ Germany } & $\begin{array}{l}\text { There are a total of } 1.03 \text { million } \\
\text { women-owned businesses in } \\
\text { Germany. Women-owned and } \\
\text { managed businesses having annual } \\
\text { turnover of at least Euro } 16620 \\
\text { nmber } 552000 \text {, represent } 18 \% \text { of } \\
\text { the total in this group, and provide } \\
\text { jobs for } 2 \text { million employees. }\end{array}$ & 2000 & Kay, et al (2003) \\
\hline & Their turnover is in total 232 & & \\
\hline
\end{tabular}




\begin{tabular}{|c|c|c|c|}
\hline & $\begin{array}{l}\text { billion, approx. } 6 \% \text { of the overall } \\
\text { turnover or } 11 \% \text { of the turnover } \\
\text { gained by owner managed firms. }\end{array}$ & & \\
\hline Sweden & $\begin{array}{l}\text { Women start } 28 \% \text { of genuinely } \\
\text { new firms and employ on average } \\
0.6 \text { time full employees compared } \\
1.7 \text { for men. }\end{array}$ & 2001 & (ITPS, 2002) \\
\hline South Korea & $\begin{array}{l}\text { Women owned and managed firms } \\
\text { represent } 36 \% \text { If all firms }(n=1.1 \\
\text { million). }\end{array}$ & 2001 & $\begin{array}{l}\text { Korean National } \\
\text { Statistics Office } \\
\text { Korea } \\
\text { Federation of } \\
\text { Small Business }\end{array}$ \\
\hline United Kingdom & $\begin{array}{l}\text { Women represent } 26 \% \text { of the } 3.2 \\
\text { million self employed }(n=824 \\
659)\end{array}$ & 1999 & $\begin{array}{l}\text { Carter, et al } \\
(2001)\end{array}$ \\
\hline United States & $\begin{array}{l}\text { Women owned and managed firms } \\
\text { represent } 28 \% \text { of the } 23 \text { million } \\
\text { firms ( } \mathrm{n}=6.4 \text { million) and they } \\
\text { provide employment for } 9.2 \\
\text { million people. That represents } 9 \% \\
\text { of all employed in the private } \\
\text { sector. }\end{array}$ & 2002 & US Census \\
\hline
\end{tabular}

It's a fact that the number of women in business world is very less. By this table we can explain our point -

The United Nation economic commission for Europe also has similar data that can allow estimation of the importance of women entrepreneurship.

While we can't assume that every firm included represents an independent firm, we can surely assume that the absolute majority represents privately held independent firms, thus making the available data relatively reliable for our purposes of establishing the importance of women's entrepreneurship. In all countries surveyed, women represent the minority of the employers and own account workers but there are important variations among the countries. The lowest shares of women employers are found to vary between $15 \%$ and $19 \%$ and the highest shares vary between $29 \%$ and $35 \%$ when excluding the extreme cases at both ends (which might be unreliable).

In total, for the 28 countries that have data available for the year 2000 , we find close to 10.1 million women employer and own account workers. Hence women employers and own account workers represent a substantial part of the entrepreneual economy. However, we are still unable to estimate their economic impact in terms of employment, achieved sales or GDP growth.

No doubt that woman has a relatively weaker position than men in society. They are facing Parda Pratha, homely responsibilities and no recognition, family work load but no money. Most specifically for women's entrepreneurship, we should try to change the interests and attitude of women and society. We feel that many women entrepreneurs are busy in retailing and simple manufacturing with very little growth potential or they are just focusing on education and health care. If women entrepreneurs will come in the picture of business, Indian society will increase its social capital with social, political, legal, cultural and business values.

Till now, we are not familiar with women entrepreneurs but we can divide them into three parts (A) Big Scale Business Women (B) Medium Scale Business Women (C) Small Scale Business Women. Medium and Small Scale Business Women cannot come in counting because they are not highlighted. By this table we can show the percentage of self-employed women in selected Asian countries -

Table 2 - Self-employment for women in Selected Asian countries (percentage)

\begin{tabular}{|l|l|l|l|l|l|}
\hline Category & $\begin{array}{l}\text { Nepal } \\
\mathbf{( 1 9 9 1 )}\end{array}$ & $\begin{array}{l}\text { Thailand } \\
\mathbf{( 1 9 9 3 )}\end{array}$ & $\begin{array}{l}\text { The } \\
\text { Philipines } \\
(\mathbf{1 9 9 0 )}\end{array}$ & $\begin{array}{l}\text { Pakistan } \\
\mathbf{( 1 9 9 2 )}\end{array}$ & $\begin{array}{l}\text { Bangladesh } \\
\mathbf{( 1 9 9 5 - 9 6 )}\end{array}$ \\
\hline Employer & 0.36 & 0.80 & - & 1.20 & 0.10 \\
\hline $\begin{array}{l}\text { Self- } \\
\text { employed }\end{array}$ & 83.69 & 18.20 & 31.20 & 42.40 & 7.60 \\
\hline Employee & 11.69 & 31.40 & 46.10 & 34.20 & 8.70 \\
\hline $\begin{array}{l}\text { Unpaid } \\
\text { Family }\end{array}$ & 3.54 & 49.60 & 22.70 & 22.20 & 77.40 \\
\hline
\end{tabular}




\begin{tabular}{|l|l|l|l|l|l|}
\hline Worker & & & & & \\
\hline & 100.00 & 100.00 & 100.00 & 100.00 & 100.00 \\
\hline
\end{tabular}

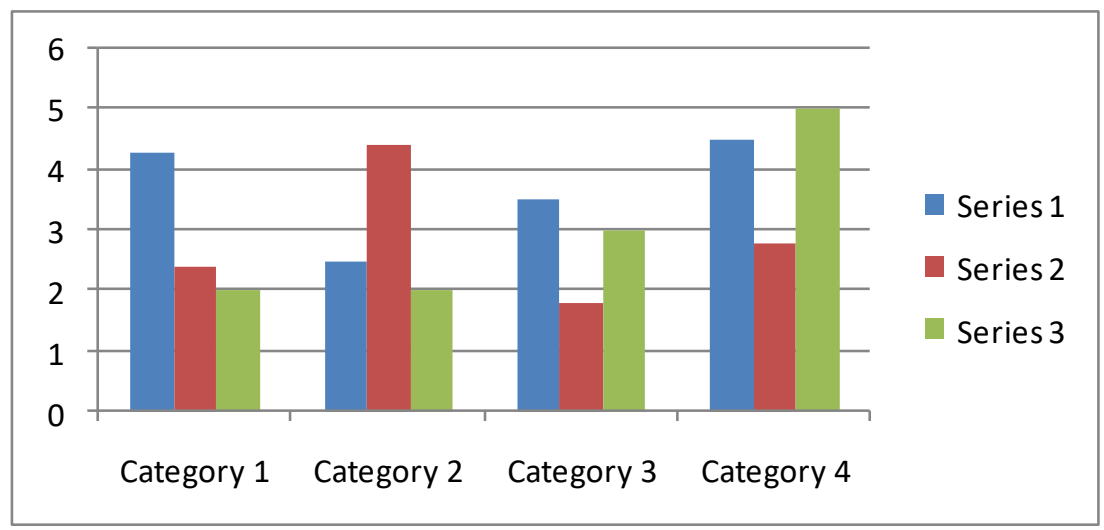

Source : Karim (2000), page

To know the involvement of women in business, we can quote these lines, which has been published in 'India Together Homepage' at www.google.com -

(a) Gujarat: Women's Dairy Cooperatives - Traditional India's dairy cooperative societies have been running by men, but this is gradually changing. Today, $18 \%$ of Cooperative members are women, and nearly all 2500 women cooperatives are functioning in the country. Sunanda Nehru Ganju reports from Gujarat, where new livelihoods for women are being established this way. (Gujarat, September 2005)

(b) Technology transforms rural Women - Women and men from more than 300,000 families in 2,500 villages of Madhya Pradesh, Chhattisgarh and Jharkhand have benefitted from the science and technology applied for rural transformation (START) Project. Shruti Gupta profiles the project and its impact. (April, 2003)

(c) Barefoot, female and a social engineer - The social work research centre addresses community problems by building people's skills, pacing the solutions in their own hands. The "Barefoot" solar engineers Provide ample evidence of the success of this approach. Drawn from mostly illiterate families, they have established for themselves a livelihood based on skill, and gained the responsibilities of their communities.

Here are some lines, which are published in India Together of Monday 02 April 2007.

\section{Resources For Women Business Owners}

Some associations are helping women entrepreneurs in business. SCORE (Counsellors of America's small Business) has assembled the list of hotlinks to useful websites for women entrepreneurs:

- Alliance of Business Women International

- American Business Women's Association

- Association for Enterprise Opportunity (AE0)

- Association of Women's Business Centres (AWBC)

- Athena Foundation

- Business Women's Network

- Centre for Women's Business Research

- Centre for Women and Enterprise Community Entrepreneurs Programme

- Committee of 200

- Count me In

- Digital Women

- Direct Selling Women's Association

- ewomen Network. Com.

- Franchise Solutions for Women

- Key Bank

- Ladies who launch 
- Make Mine a and Million Business Program

- Mompreneurs Online

- National Association for Female Executives (NAFE)The Nationals Business Council

- The National Business Owners Corporation (NWBOC)

- Organization of women in International Trade (OWIT)

- SBA's online women Business centre

- Springboard Enterprises

- Web Monz.com

- Wome-21.gov

- Womersbiz.us

- Women's Business Enterprise National Council (WBENC)

- WomenOwned.com

- Women Impacting Public Policy (WIPP)

- Women's Business centres (WBC)

- Women's Presidents Organizations (WPO)

Some governmental and non-governmental organization is working for women entrepreneurs. They select, prepare, trained, settled, developed and promoted them in global world. Some are here-

- Federation of Societies of Women Entrepreneurship (FSWE).

- Small Entrepreneurship Development Institute of India (DEDII)

- District Industries Centers (DIC)

- Development of Women \& Children in Rural Areas (DWCRA)

- Integrated Rural Development Programme (IRDP)

- Prime Minister Rojgar Yojana (PMRY)

- Training of Rural Youth for Self Employment (TRYSEM)

- Women's Corporate Finance Corporation (WCFC)

- Finance Assistance Through Women's Development Corporations (FAWDC)

- National Backward Classes' Finance and Development Corporation (NBCFDC)

- National Safai Kramchari Finance and Development Corporation (NSKFDC)

IV. STUDY OF WOMEN ENTREPRENEURS IN MEERUT CITY (U.P.) INDIA

Meerut city being a part of Uttar Pradesh state nearby Delhi has now been declared as a metro city which is developing day by day. The city is famous for sports items, jewellery items, knife-scissor udyog for the starting of freedom revolution. Surajkund, etc. came in contact with many women entrepreneurs in Meerut city, which established their business themselves and today they are strong pillars of the city. When we asked them about the problems to make themselves as women entrepreneurs, they told us -

1. Lack of family support, capital freedom, confidence and faith and right public or private institution.

2. Lack of means of travelling for women in the mean courses of business at the time of dealings.

3. Women because of having a day by day responsibility for the family have less time to invest in the development of their firms.

4. People in general view of entrepreneurship think that it is a masculine and perceive entrepreneurship to be male dominating.

5. There are less business fields for women which is a major cause of women's failure.

\section{SOLUTION FOR THE BETTER CONDITIONS OF WOMEN ENTREPRENEURS}

A specific solution for solving women's difficulties for obtaining financing has been microfinancing. Microfinance is financial institution that has become extremely popular especially in developing economies even if there are such programmes in the European Union and the United States. This example of well known programmes is the pioneering grammen bank in Bangladesh. The Banco solodario (Bancosol) in Bolovia and the Bank Rakyat in Indonesia. If women can be more successful than men in service sector then they can be in business sector also. They have to be bold, confident and capable of doing every type of work and also have patient when others are passing comments about different financial institutions such as banks, mutual funds investment are providing funds to finance them in the business. After all my study on this topic I came to the conclusion that "Man mein hai vishwas poora hai vishwas, hum honge kamyab ek din."

Or we can say that -

"Main akela chala tha janibe manjil magar, log saath aate gaye karva banta gaya." 


\section{REFERENCES:}

[1] A report of $2^{\text {nd }}$ OECD conference of Ministers responsible for small-medium sized enterprises (SMEs) on the topic of Women's Entrepreneurship: Issues and Policies, Turkey, 3-5 June 2004.

[2] Adler, P.S. and S.W. Kwon. 2002. Social Capital: Prospects for a new concept. Academy of Management Review. 27 (X): 17-40.

[3] Aldrich, H. and C. Zimmer. 1986. Entrepreneurship through social networks in D.L. Sexten and R.W. Smilor (Eds) The Art and Science of Entrepreneurship: 3 -24. Cambridge, Massachusetts. Ballinger Publishing Company and R.S. Burt, 2000. 'The network entrepreneuers in R. Swedberg (Ed.) Entrepreneurship: the social sciences view, 281-307, Oxford : England : Oxford University Press and M. Granovetter, 1985, Economic action and social structure : The problem of embededness. American Journal of Sociology, 9 (3) : 481-510 and M.S. Gransovetter, 1973, The strength of the weak ties, American journal of Sociology, 78 (6) 1360-1380.

[4] Bajpai A.D.N, Mishra S.K.(2007). Women Empowerment And Reproductive Behaviour. New Delhi: Classical Publishing Company. Page No. 138.

[5] Brush, C.G. (1992). Research on Women Business Owners: Past trends, A new perspective and future direction. Entrepreneurship: Theory and Practice, 16 (4) : 5-30.

[6] Dua, Radha. (2005) .Working Women - Their adjustment and familiar role expectations. Delhi: Neelkamal prakshan.

[7] Gaur, G.D. and J.L. Singh (Article). (2002) - "Growth of informal sector in developing economic with special reference to India in the book - Women in Unorganized sector : The concept of unorganized sector : Problems and prospects" Delhi : Sunrise Publication. Page- 173-174.

[8] Groocock, Veronica. (1988). Women Means Business (A Success And Survival Guide For The Woman Executive). London: Ebury Press.

[9] Kapoor , P. (1970). Marriage and the working women in India. New Delhi, vikas publishing house.

[10] Myrdal, A and V Klein. (1968). Womens two Roles- home and work. London: Routledge \& Kegan Paul Ltd.

[11] Morduch, J. (1999). The Microfinance Promise. Journal of Economic Literature. X XXVII (December): 1569-1614.

[12] Lin, N. (1999). Social networks and status attainment. Annual Review of Sociology. 25 :467-487.

[13] Rahman, Zainab. (2005). Women and Society. Delhi: Kalpaz Publications. Page no. Forward.

[14] Report of organization for economic cooperation and development, Istanbul, Turkey, 3-5 June2004, page no. 6.

[15] Ross, A.D. (1961): The Hindu family in its urban setting. Toranto: University of Toranto Press.

[16] Shukla, M.B. (2003). Entrepreneurship and Small Business Management. Allahabad

[17] Stephen, Anita (2006). Communication Technologies and Women

[18] Saini, Dr. Shashi (Dec. 2016). Globalization and Women Professionals is an Industrial City. in Research Journal Philosophy \& Social Sciences. Vol 42. No. 02. Edited By Dr Rajni Bala, Delhi: Journal Anu Books.

[19] Sethi, Amarjeet Singh and B P Singhal ( Jan.- Dec. 2015). "Entreprenurship with a Difference -To Make A Difference : A Critique of Social Entrepreneurs in

[20] Uttrakhand .”(Research Paper) in Vidya International Journal of Management Research Volume 3 No.12

[21] Tiwari, Dr. Sanjay and Dr. Anshuja Tiwari (2007). Women Empowerment and Economic Development. New Delhi: Sarup \& Sons. www.score.org 